\title{
Application of new architectural and planning solutions to create an ecological city (on the example of Shanghai, China)
}

\author{
Shanshan $\operatorname{Van}^{1}$, Alexey Cheremisin ${ }^{2}$, Alexey Glinushkin ${ }^{2}$, Victor Krasnoshchekov ${ }^{1}$, Roman Davydov ${ }^{1, *}$ and Victoria \\ Yushkova ${ }^{3}$ \\ ${ }^{1}$ Peter the Great St.Petersburg Polytechnic University, 195251, Saint Petersburg, Russia \\ ${ }^{2}$ All Russian Research Institute of Phytopathology, 143050, Moscow Region, Russia \\ ${ }^{3}$ Saint Petersburg University of Management Technologies and Economics, 190109, Saint Petersburg, Russia
}

\begin{abstract}
This article represents the results of research on improvement of the Shanghai micro-district with the use of selected eco-friendly architectural and planning solutions and identification of the main ways to solve the problem of eco-urban development in Shanghai which are the following: land management, population management, clean energy sources and "green" consumption. Research is based on analysis and calculations on main trends of the theory and practical experience of construction of ecocities in China and in the world.
\end{abstract}

\section{Introduction}

The Chinese and world experience in the development and implementation of architectural and planning solutions aimed at environmental modernization and reconstruction of the urban environment. Possibilities and prospects of development of cities to improve living conditions of people, enhance the quality of the environment, harmonization of relations between the city and nature are considered. This concerns the planning of urban areas, the creation of an environmentally balanced infrastructure that helps to meet the multifaceted needs of residents and to develop economic and environmental measures. For example, the city of Shanghai considers the strategic goal of the development as ecological city. It includes the measures for reasonable planning of territories, the establishment and maintenance of green areas, a high level of biodiversity, promoting the use of environmentally friendly sources of energy, optimizing the transport structure, protection of spiritual and cultural values, historic heritage, control of the population.

The one of the most important elements in the development of the territories of former industrial zones is the monitoring of quality of soil, water resources, air and other objects to determine ways of further land use [1-4]. The highest priority in control of environmental quality is given to express methods [512]. In some cases, the projecting and construction of hydraulic structures is necessary for the development of these territories [13-16]. It should also be noted that solar energy (along with another renewable energy sources) is a one of the great prospect for providing electricity for municipal needs of territories under reconstruction and modernization in such countries as China [17]. All these aspects should be taken into account at innovative development of territories under environmentally reconstruction from different points of view including the economy and the construction business [18-27]. An important factor in the development of such territories is solar energy [28-39]. This is especially true for China.

\section{The objects of the research and their features, novelty of results and discussion}

The scientific novelty consists in development of the methodology of environmental assessment of regional land use with application of the method of multicriteria analysis and calculation of key parameters on the example of a particular district of Shanghai. The authors developed the criteria and determined the content of the assessment with the choice of formulas for calculating the coefficients of the significance of the basic parameters taking into account the environmental (ecological) potential of the territory, factors of economic activity, natural conditions. The method of the imposed analysis of factors is applied, the planning structure of sites is proved. Based on carried out calculations, the project of improvement of the Shanghai micro-district was justified and developed using the selected environmentally friendly architectural and planning solutions and identifying the main ways to solve the problem of eco-urban development in Shanghai: land management,

\footnotetext{
${ }^{1}$ Corresponding author: romanvproze@gmail.com
} 
population management, environmentally friendly energy sources and "green" consumption [17].

On the base of analysis of current situation with "green" technologies in Shanghai, it was revealed that the rapid and environmentally unfriendly development of the economy has also led to serious environmental problems in the city, especially in the industrial zone of Shanghai. Currently, it is in the phase of post-industrial transformation at the late stage of industrialization. With the development of urbanization and the adjustment of the structure of industry, the old industrial areas of China and the city are gradually disappearing, due to many remnants of the past which are incompatible with the modernity. Former industries are gradually giving way to new, higher technological level. It is necessary to continue research and organize development in accordance with the conditions of urban planning. Against this background, Taopu district needs to be transformed into a modern industrial zone, and the environment needs to be restored. At the same time, this district is one of the few in the outer ring of Shanghai, and excellent opportunities for development are provided [40, 41].

Taopu district was chosen as the main area of this planning. First, regional functional units and roads are analyzed. The methods of analysis, calculation, modeling, forecasting and comparison are used to assess the degree of contamination and ecological potential of the land. Calculated ecological capacity of the land should promote to ascertain the possibility of their redevelopment, to estimate and nominate new solutions for the implementation of the ecological concept, through the planning of the industrial zone Taopu that help to increase the value of land and to develop the surrounding land use, and to provide residents recreational space. The process of transforming the image of the city and the image in the urban industry is expected to be positive. The economic and environmental benefits of urban renewal of large industrial areas such as Wusong and Gaohua are based on an ecological concept for $15 \%$ of the land used to promote regional functional transformation, which will open up great opportunities for the city with a wide choice of open spaces. Adhering to the concept of sustainable development, an advanced incubator of new technologies is being created in Shanghai.

\subsection{Environmental assessment of regional land use.}

\subsubsection{Determining the content of the assessment}

The content of the assessment of the reuse of industrial heritage is determined by its characteristics and can be determined at two levels with the identification of the environmental potential of the site.

1. Characteristics of the site itself, such as environmental contamination, the state of industrial operation, the scale of land use, the intensity of development of the territory as well as historical and cultural values.
2. Belonging to a particular industry. Transport accessibility, well-established communications and availability of resources. Such conditions as distance from the metro, connection with the city center, water supply and sewerage system are taken into account. The high cost of land can be due to the abundant resources of the environment and excellent transport conditions. These features are easily captured by the market, and the value of reuse in this case increases.

\subsubsection{Choosing an assessment model}

At present, the environmental potential assessment methods are usually based on qualitative and quantitative analysis of baseline data with further identification of significant factors of environmental impact, choice of suitable environmental indicators and calculation of parameters under assessment. Using geographic information systems (GIS) with spatial database in this case is much recommended. The main environmental potential assessment methods are analytical and numerical which use the data of environmental monitoring with application of express methods in situ and in lab-scale conditions. This is very important whether it is an assessment of the suitability of urban land for any economic activity or a potential assessment of the adjustment of industrial land use. The final available capacity is estimated by weighing the factors that affect the ultimate goal. On the base of analysis of different conditions, data and parameters of the former industrial zone of Taopu authors of this article have found that for environmental potential assessment could be most reliable the methods based on spatial decisions for industrial land management [41], which combine the characteristics of the sites and the content of the environmental potential, as well as possibilities of its partial modification. From this point of view various assessment criteria and factors should be determined including the contamination coefficients. The decisive role of the environmental potential of industrial heritage reuse is established after contamination exceeds a certain level. The following assessment model is used:

$$
Y=P \cdot\left(r_{1} \cdot w_{1}+r_{2} \cdot w_{2}+r_{3} \cdot w_{3}+r_{n} \cdot w_{n}\right)
$$

where $Y$ is a value of environmental potential; $P$ is a contamination degree coefficient (in a range that can be changed in the near future, the contamination degree is 1 and the contamination level is much higher than the norm; the norm is if the level of contamination degree is 0$) ; r_{1} \ldots . . r_{n}$ are rank correlation coefficients for assessment criteria with numbers $1 \ldots . . \mathrm{n} ; w_{1}$ to $w_{n}$ are weighting coefficients.

\subsubsection{Determination of weighting factors}

In the course of this study it is assumed that the number of factors assessed is small and these factors are relatively similar in importance. For this purpose equal weight division is accepted. The weights (significance levels) of the nine assessment factors, such as 
environmental contamination, land use, industrial land use, development intensity, historical and cultural value and so on (see Table 1), are 1/9.

\subsubsection{Normalization of indicators}

Normalization of indicators is a process of transforming the database to the form corresponding to the normal (reduced) forms includes normalization of the forward indicator and normalization of the reverse index. For the forward indicator, the formula looks like:

$$
X_{i j}=\frac{R_{i j}-R_{j}^{\min }}{R_{j}^{\max }-R_{j}^{\min }}
$$

where $X_{i j}$ is $j$-th unit element of assessment of normalized value coefficient of $i$-th object;

$R_{i j}$ is the actual value of the $j$-th individual element, which allows to determine the coefficient of the $i$-th object;

$R_{j}^{\max }$ is the maximum actual value of the assessment factor of the $j$-th individual element; $R_{j}^{\min }$ is the minimum of the actual values.

\subsubsection{Assessment criteria}

The assessment criteria are given in Table 1.

Table 1. Table of factors for assessing the environmental potential of industrial heritage reuse

\begin{tabular}{|c|c|c|c|c|c|}
\hline $\begin{array}{l}\text { Number of } \\
\text { assessment } \\
\text { criterion } \\
(1 \ldots \mathrm{n})\end{array}$ & $\begin{array}{c}\text { Classification } \\
\text { of content }\end{array}$ & & The assessment criteria & $\begin{array}{l}\text { The } \\
\text { weighting } \\
\text { factor }\end{array}$ & - \\
\hline 1 & & $\begin{array}{l}\mathrm{T} \\
\mathrm{h} \\
\mathrm{e}\end{array}$ & $\begin{array}{l}\text { Determination of contamination } \\
\mathrm{n} \text { status based on relevant } \\
\text { research results }\end{array}$ & $1 / 9$ & $\uparrow$ \\
\hline 2 & & $\begin{array}{l}\text { Scale of } \\
\text { industrial land } \\
\text { use }\end{array}$ & $\begin{array}{l}\text { Belonging to the industrial } \\
\text { heritage zone }\end{array}$ & $1 / 9$ & $\uparrow$ \\
\hline 3 & & $\begin{array}{l}\text { The status of } \\
\text { industrial } \\
\text { operation }\end{array}$ & $\begin{array}{l}\text { Total abandonment, partial } \\
\text { abandonment, inefficient } \\
\text { operation, efficient operation }\end{array}$ & $1 / 9$ & $\downarrow$ \\
\hline 4 & & $\begin{array}{l}\text { Intensity of } \\
\text { development }\end{array}$ & $\begin{array}{l}\text { Ratio of plots with different } \\
\text { levels of industrial and economic } \\
\text { development }\end{array}$ & $1 / 9$ & $\downarrow$ \\
\hline 5 & & $\begin{array}{l}\text { Historical and } \\
\text { cultural value }\end{array}$ & $\begin{array}{l}\text { Presence or absence of protected } \\
\text { objects of historical and cultural } \\
\text { heritage }\end{array}$ & $1 / 9$ & $\uparrow$ \\
\hline 6 & \multirow{4}{*}{$\begin{array}{l}\text { External } \\
\text { influence }\end{array}$} & $\begin{array}{l}\text { Structuring and } \\
\text { status of the } \\
\text { territory } \\
\text { (character of } \\
\text { administrative } \\
\text { and territorial } \\
\text { structure) }\end{array}$ & $\begin{array}{l}\text { Division of a city or district into } \\
\text { territorial entities caused by } \\
\text { natural, political, economic, } \\
\text { ethnic, national and other factors, } \\
\text { taking into account status of } \\
\text { different territories and character } \\
\text { of interrelations between them }\end{array}$ & $1 / 9$ & $\uparrow$ \\
\hline 7 & & $\begin{array}{l}\text { Attraction to the } \\
\text { city center }\end{array}$ & Distance from city center & $1 / 9$ & $\downarrow$ \\
\hline 8 & & $\begin{array}{l}\text { Impact of } \\
\text { transport transit } \\
\text { (including } \\
\text { railway transit) }\end{array}$ & $\begin{array}{l}\text { Distance from transport transit } \\
\text { ways, stops, including metro } \\
\text { stations, surface railway transit } \\
\text { stations }\end{array}$ & & $\downarrow$ \\
\hline 9 & & $\begin{array}{l}\text { Influence of the } \\
\text { river system }\end{array}$ & Distance from the river system & & $\downarrow$ \\
\hline
\end{tabular}

$\uparrow$ Positive indicator $\downarrow$ The reverse index

The current status of each site depends mainly on the nature of the land, the degree of contamination, the state of industrial operation, the distance from transport stops, the distance from the river system and elements of historical and cultural value. The final results are shown in Table 2

By analyzing the superposition of each factor, it can be found that the site No 2 is currently heavily contaminated as a result of intensive industrial activity and the contamination assessment coefficient is 1.0 i.e. it is not suitable for any use in the near future and can first be observed by monitoring tools with preliminary contamination assessment, landscaping indicator and planning of appropriate protection measures in the short term.

The comparison shows that the overall level of contamination on the Eastern side is relatively low, while the sub-blocks of the Central sector, such as No. 10, No. 11, No. 21-24, have some controlled 
contamination, and the sections No. 21-25 are due to environmental factors. As can be seen from the assessment, the environmental potential for reuse is very high. From the current situation, it has really gotten outstripping development, and the reuse feature is mainly recommended for office space organization.

Table 2. Statistics of environmental potential assessment elements for reuse in the former industrial zone of Taopu

\begin{tabular}{|c|c|c|c|c|c|c|c|}
\hline $\begin{array}{l}\text { Number of } \\
\text { land plot }\end{array}$ & $\begin{array}{l}\text { The status } \\
\text { of } \\
\text { contaminati } \\
\text { on }\end{array}$ & $\begin{array}{c}\text { The } \\
\text { industrial } \\
\text { scale of the } \\
\text { land use }\end{array}$ & $\begin{array}{l}\text { The status } \\
\text { of } \\
\text { industrial } \\
\text { operation }\end{array}$ & $\begin{array}{l}\text { Intensity of } \\
\text { develop- } \\
\text { ment }\end{array}$ & $\begin{array}{l}\text { Historical } \\
\text { and } \\
\text { cultural } \\
\text { value }\end{array}$ & & $\begin{array}{l}\text { Distance } \\
\text { from river } \\
\text { system }\end{array}$ \\
\hline 1 & 0.20 & 0.36 & 0.3 & 0.5 & 0 & 0.26 & 0.89 \\
\hline 2 & .00 & 0.82 & 0.6 & 0.5 & 0.5 & 0.31 & 0.88 \\
\hline 3 & 0.80 & 0.41 & 0.3 & 0.5 & 0 & 0.14 & 0.59 \\
\hline 4 & 0.20 & 0.19 & 0.3 & 0.5 & 0 & 0.01 & 0.42 \\
\hline 5 & 0.20 & 0.00 & 0.3 & 0.5 & 0 & 0.00 & 0.32 \\
\hline 6 & 0.80 & 0.29 & 0.3 & 1.0 & 0 & 0.51 & 0.81 \\
\hline 7 & 0.20 & 0.44 & 0.3 & 0.5 & 0 & 0.52 & 0.93 \\
\hline 8 & 0.20 & 0.38 & 0.3 & 0.5 & 0 & 0.76 & 0.94 \\
\hline 9 & 0.20 & 0.30 & 0.3 & 0.5 & 0 & 0.57 & 0.88 \\
\hline 10 & 0.60 & 0.27 & 0.6 & 0.5 & 1.0 & 0.50 & 0.72 \\
\hline 11 & 0.60 & 0.29 & 0.3 & 0.5 & 0 & 0.37 & 0.58 \\
\hline 12 & 0.20 & 0.39 & 0.3 & 0.2 & 0 & 0.26 & 0.42 \\
\hline 13 & 0.20 & 0.26 & 0.3 & 0.5 & 0 & 0.81 & 0.88 \\
\hline 14 & 0.20 & 0.28 & 0.6 & 0.5 & 0 & 0.70 & 0.73 \\
\hline 15 & 0.20 & 0.29 & 0.6 & 0.5 & 0 & 0.53 & 0.57 \\
\hline 16 & 0.20 & 0.36 & 0.3 & 0.2 & 0 & 0.53 & 0.41 \\
\hline 17 & 0.20 & 0.34 & 0.3 & 0.5 & 0 & 0.45 & 0.27 \\
\hline 18 & 0.20 & 0.09 & 0.3 & 1.0 & 0 & 0.48 & 0.21 \\
\hline 19 & 0.20 & 0.07 & 0.3 & 1.0 & 0 & 0.77 & 0.93 \\
\hline 20 & 0.60 & 0.78 & 0.3 & 0.5 & 0 & 0.97 & 0.94 \\
\hline 21 & 0.60 & 0.59 & 0.6 & 0.5 & 0 & 0.92 & 0.81 \\
\hline 22 & 0.60 & 0.44 & 0.6 & 0.5 & 0 & 0.86 & 0.75 \\
\hline 23 & 0.60 & 0.27 & 0.3 & 0.5 & 0 & 0.65 & 0.58 \\
\hline 24 & 0.60 & 0.28 & 0.3 & 0.5 & 0 & 0.80 & 0.56 \\
\hline 25 & 0.60 & 0.30 & 1.0 & 1.0 & 0.5 & 0.78 & 0.41 \\
\hline 26 & 0.20 & 0.33 & 0.3 & 0.5 & 1.0 & 1.00 & 0.41 \\
\hline 27 & 0.20 & 0.72 & 0.3 & 0.5 & 1.0 & 0.91 & 0.24 \\
\hline 28 & 0.20 & 0.27 & 0.3 & 0.5 & 0 & 0.79 & 0.12 \\
\hline 29 & 0.20 & 0.00 & 0.3 & 0.5 & 0 & 0.71 & 0.91 \\
\hline 30 & 0.20 & 1.00 & 0.3 & 0.5 & 0 & 0.85 & 0.96 \\
\hline 31 & 0.20 & 0.44 & 0.3 & 0.5 & 0 & 0.64 & 0.70 \\
\hline 32 & 0.20 & 0.19 & 0.3 & 0.5 & 0 & 0.79 & 0.54 \\
\hline 33 & 0.20 & 0.21 & 1.0 & 0.5 & 0 & 0.96 & 0.39 \\
\hline 34 & 0.20 & 0.44 & 0.3 & 0.8 & 0 & 0.91 & 0.19 \\
\hline
\end{tabular}

\subsubsection{Overlay analysis of factors of assessment of the local plots}

Each plot is numbered based on an analysis of current land use. As an indicator of the assessment corresponds to the degree of contamination, the scale of industrial heritage, the intensity of development, cultural value, location conditions and other features. 


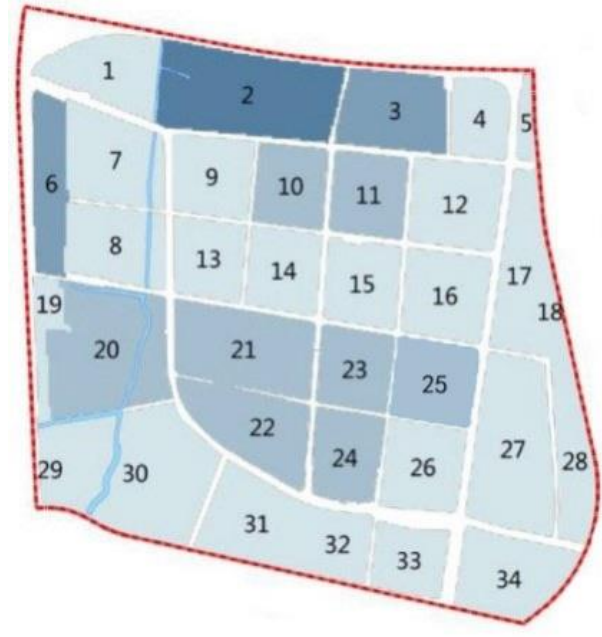

a) Schematic diagram of the results of plots assessment of contamination (the darker the color, the higher the degree of contamination)

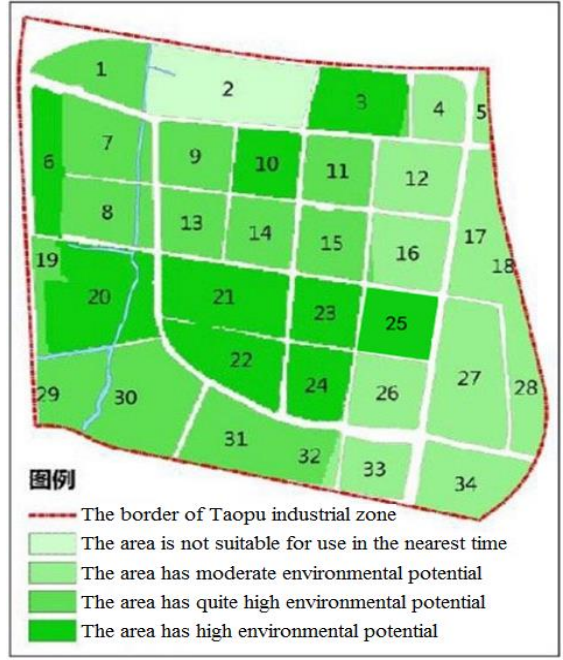

b) Schematic diagram of the results of the assessment of the environmental potential of different plots (the darker the color, the higher the environmental potential)

Fig. 1. Schemes of assessment of plots contamination levels and environmental potential of the territory, taking into account the location and numbering of sites to determine the environmental potential for reuse in the former industrial zone of Taopu.

The area was redeveloped based on the results of an

\subsubsection{Planning areas on the basis of an assessment of environmental potential.} assessment of the environmental potential of the urban areas of the former industrial zone of Taopu (see Figure 2).

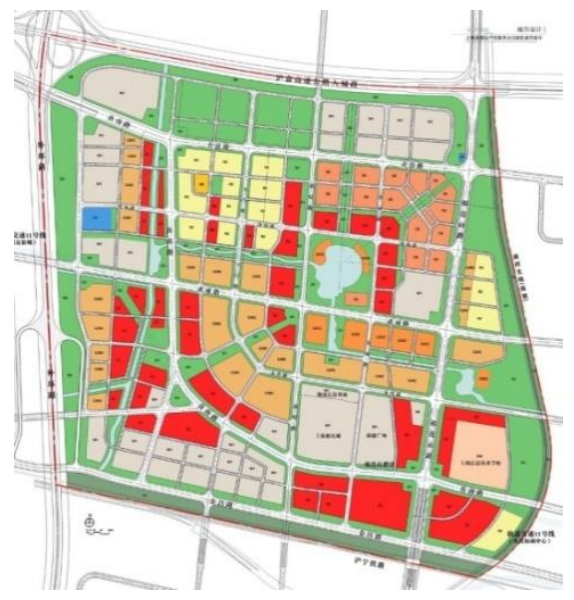

\footnotetext{
R2 Lands for housing

RS Lands for primary and secondary schools

C2R2 Lands for social institutions

C2R2 Lands for integration of the commercial workspace with the

living structure

C2 Lands for the synthesis of various activities

C8 Lands for business centres

C2C3 Lands for synthesis of business and cultural institutions

C65 Lands for professional education and training institutions

M1 Lands of former industrial infrastructure

G Lands of green areas

T1 Lands for external transport communications

U Lands for municipal objects

E Lands of water fund
}

Fig. 2. Planning for further use of the former Taopu industrial zone 


\subsection{The results of the research}

In the course of this research, the following tasks were solved.

1. The basic preconditions and tendencies of construction of eco-cities in China taking into account local features (social, cultural, economic, geographical, ecological) and world tendencies were revealed.

2. It is analyzed the current situation of green building in Shanghai, as one of the largest cities in China. Regional features of territorial planning were considered.

3. Based on the analysis of the status of land use in a particular area of Shanghai, an environmental assessment of regional land use was made.

4. There were developed the criteria and determined the content of the assessment with the choice of formulas for calculation of coefficients of significance of the parameters taking into account the ecological potential of the territory, factors of the environmental contamination and impacts of the various forms of land use and economic activities depending on functional zones of the territory, divided into sections: industrial buildings, residential buildings, green areas, transportation (road network), objects of culture.

5. Based on the overlay analysis of factors of assessment of the local block planning structure of the plots were justified with their schemes.

6. It was developed the elements of project of improvement of the Shanghai microdistrict with the use of selected eco-friendly architectural and planning solutions and identification of the main ways to solve the problem of eco-urban development in Shanghai: land management, population management, clean energy sources and "green" consumption.

\section{Conclusion}

The results of this research are of practical importance in the field of ecological territorial and architectural planning, taking into account the historical, cultural, geographical, social, economic and environmental trends in the development of megacities on the example of Shanghai and could be used in the development of new projects and solutions for environmental reconstruction and modernization of the urban environment in megacities all round the world with taking into account a range of features of different countries including Russia.

\section{References}

1. N.M. Grebenikova, K.J. Smirnov, V.V. Davydov, V.Yu. Rud, V.V. Artemiev, Journal of Physics: Conference Series, 1135(1) 012055 (2018)

2. N.M. Grebenikova, K.J. Smirnov, V.V. Davydov, V.Y. Rud, Journal of Physics: Conference Series, 1124(4) 041011 (2018)

3. N.M. Grebenikova, N.S. Myazin, V.Yu. Rud, R.V. Davydov, Proceedings of the 2018 IEEE
International Conference on Electrical Engineering and Photonics, EExPolytech 2018, 8564409 295297 (2018)

4. E.V. Rykin, A.V. Moroz, K.J. Smirnov, V.V. Davydov, V.V. Yushkova, MATEC Web of Conference, 24512002 (2018)

5. V.V. Davydov, S.V. Kruzhalov, N.M. Grebenikova, K.J. Smirnov, Measurement Techniques, 61(4) 365-372 (2018)

6. N.S. Myazin, V.V. Davydov, V.V. Yushkova, V.Yu. Rud, Journal of Physics: Conference Series, 1038(1) 012088 (2018)

7. N.S. Myazin, V.V. Davydov, V.V. Yushkova, T.I. Davydova, V.Yu. Rud, Journal of Physics: Conference Series, 917(4) 042017 (2017)

8. N.S. Myazin, V.V. Davydov, V.V. Yushkova, V.Yu. Rud, Journal of Physics: Conference Series, 1038(1) 012088 (2018)

9. R.V. Davydov, V.I. Antonov, V.V. Yushkova, N.M. Grebenikova, V.I. Dudkin, Journal of Physics: $\quad$ Conference $\quad$ Series, 1236(1) 012079 (2018)

10. N.S. Myazin, S.E. Logunov, V.V. Davydov, V.Yu. Rud', N.M. Grebenikova, V.V. Yushkova, Journal of Physics: Conference Series 929 (1) 012064 (2017)

11. V.V. Davydov, Russian Physics Journal, 42(9) 822-825 (1999)

12. V.V. Davydov, E.N. Velichko, N.S. Myazin, V.Yu. Rud', Instruments and Experimental Techniques, 61 116-122 (2018)

13. R. Davydov, V. Antonov, D. Molodtsov, A. Trebukhin, Advances in Intelligent Systems and Computing, 692 915-920 (2018)

14. R. Davydov, V. Antonov, D. Molodtsov, A. Cheremisin, V. Korablev, MATEC Web of Conference, 24515002 (2018)

15.R.V. Davydov, V.I. Antonov, D.V. Molodtsov, Journal of Physics: Conference Series, 1135(1) 012088 (2018)

16. R.V. Davydov, V.I. Antonov, A. V. Moroz, Proceedings of the 2018 IEEE International Conference on Electrical Engineering and Photonics, EExPolytech 2018, 8564378 236239 (2018)

17. V.A. Lyapishev, V.Yu. Rud, M.S. Sokolov, A.V. Cheremisin, Proceedings of the 2018 IEEE International Conference on Electrical Engineering and Photonics, EExPolytech 2018, 8564387 292294 (2018)

18. D. Tarasova, A. Staritcyna, D. Nemova, K. Andreev, MATEC Web of Conferences, 5301007 (2016)

19. V. Maslak, N. Nasonkina, V. Sakhnoskaya, S. Antonenko, D. Nemova, Procedia Engineering, 117(1) 985-994 (2015) 
20. V. Mushchanov, V. Sievka, A. Veshnevska, D. Nemova, Procedia Engineering, 117(1) 10181026 (2015)

21. M. Petrichenko, N. Vatin, D. Nemova, N. Kharkov, A. Staritcyna, Applied Mechanics and Materials, 627 297-303 (2014)

22. T. Fejling, E. Torosyan, O. Tsukanova, O. Kalinina, IOP Conference Series: Materials Science and Engineering, 497(1) 012027 (2019)

23. V. Vilken, O. Kalinina, S. Barykin, E. Zolotova, IOP Conference Series: Materials Science and Engineering, 497(1) 012037 (2019)

24. O. Kalinina, E. Balchik, S. Barykin, MATEC Web of Conference, 23904021 (2018)

25. V. Vilken, O. Kalinina, A. Dubgorn, E35 Web of Conference, 3303012 (2018)

26. A. Bril, O. Kalinina, A. Levina, E35 Web of Conference, 3303004 (2018)

27. R. Davydov, M. Sokolov, W. Hogland, A. Glimushkin, A. Markaryan, MATEC Web of Conference, 24511003 (2018)

28. I.A. Zharikov, R.V. Davydov, V.A. Lyapishev, V.Yu. Rud, Yu.V. Rud, A.P. Glinushkin, Journal of Physics: Conference Series, 917(5) 052011 (2017)

29. I.S. Kudryashova, V.Yu. Rud, V.C. Shpunt, Yu.V. Rud, A.P Glinushkin, Journal of Physics: Conference Series, 741(1) 012106 (2016)

30. V. B. Fadeenko, V. Yu. Rud, Yu.V. Rud, A.P Glinushkin, V.C. Shpunt, W. Hogland, Journal of Physics: Conference Series, 1038(1) 012030 (2018)

31. N. Mahmoud, W. Hogland, M. Sokolov, V. Rud, N. Myazin, MATEC Web of Conference, 24506012 $\underline{(2018)}$

32. J. Stenis, W. Hogland, M. Sokolov, V. Rud, R. Davydov, IOP Conference Series: Materials Science and Engineering, 497(1) 012061 (2019)

33. R.V. Davydov, V.Yu. Rud, Yu.V. Rud, E.I. Terukov, Journal of Physics: Conference Series, 1124(8) $081039 \underline{\text { (2018) }}$

34. A.V. Moroz, V.V. Davydov, V.Yu. Rud, Yu.V. Rud, V.C. Shpunt, A.P. Glinushkin, Journal of Physics: Conference Series, 1135(1) 012060 (2018)

35. I.V. Bondar, V.Yu. Rud, Yu.V. Rud, D.V. Lozhkin, Semiconductors, 45(7) 912-916 (2011)

36. V.F. Gremenok, V.Yu. Rud, Yu.V. Rud, S.A. Bashkirov, V.A. Ivanov, Semiconductors, 45(8) 1053-1058 (2011)

37. V.Yu. Rud, Yu.V. Rud, V.F. Gremenok, E.I. Terukov, B.K. Barinov, Y.W. Song, Semiconductors, 46(2) 221-224 (2012)

38. N.S. Myazin, K.J. Smirnov, V.V. Davydov, S.E. Logunov, Journal of Physics: Conference Series, 929(1) 012080 (2017)

39. K.J. Smirnov, V.I. Medzakovskiy, V.V. Davydov, M.G. Vysoczky, S.F. Glagolev, Journal of Physics: Conference Series, 917(6) 062019 (2017)

40. X. Li, W. Liu. Status Quo, Urban Planning Journal, 4 23-29 (2011)
41. Y. Zhang. Urban Planning Journal, 5 1-8 (2012) 